\title{
小樽湾におけるドップラーレーダーによる海面状況の観測
}

\author{
石田廣史*・林＼cjkstart美鶴*・脇川祐樹**・上田

\section{The Sea State Observation by the Doppler Radar in Otaru Bay, Hokkaido}

博***

\author{
Hiroshi ISHIDA, Mitsuru HAYASHI, \\ Yuhki WAKIGAWA and Hiroshi UYEDA
}

\begin{abstract}
The observation was made to examine the relationship between the sea state and radar sea echo signals and to obtain information and the characteristics of the sea state from the signals by the doppler radar in Otaru Bay, Hokkaido for 49 days in total from the 14th of December, 1991 to the 31st of January, 1992. Here, the doppler direction is defined as a direction in which the maximum doppler shift of radar sea echo signals occurs, and the doppler speed of the signals is also done as an average doppler speed on that doppler direction.

It was found out that the doppler direction and speed were not related with the direction and speed of winds and currents, but related strongly and agreed so well with the propagating direction and phase speed of waves, respectively. The doppler speed is proportional to the phase speed of the significant waves estimated from the observed wave period with the $1 / 10$ to $1 / 3$ slope. It is concluded that the doppler shift of the radar sea echo signals is mainly caused by the wave propagation even though it might be slightly effected by winds and currents.
\end{abstract}

\section{1.はじめに}

波浪などの海面状況に関する情報は航海の安全や 運航効率の向上、そして防災などにとって必要不可 欠なものと考之られる。従来より、海面状況に関す る情報の内、波浪に関する情報収集システムについ てはブイや船舶用に水圧や超音波、そして電磁波な ぞを利用した様々な波浪計が多く開発されてきた。 また、舶用レーダ一の海面反射信号のPPI画像のパ ターン解析から、卓越波の波長や波向方位（パター ン方位）などの情報を得る舶用レーダー波浪観測シ ステム(1),(2),(3),(4)なども開発されてきた。

本報告では、北海道小樽湾で1991年末から1992年 にかけて合計49日間にわたって実施したドップラー レーダーによる海面状況の観測データを基に、ドッ
プラーレーダーの海面反射信号と海面状況の関係に ついて解析し、それらの特性について報告する。こ のようなドップラーレーダーによる海面反射信号と 海面状況の相互関係や、特性に関する解析的研究は これまであまり他では見受けられず、両者の相互関 係や特性を知る上で重要であると考えられる。

\section{2. 観測概要}

\section{1 観測地点と期間}

ドップラーレーダー観測は図 1 に示すように、 1991年12月14日から1992年1月31日の合計49日間に わたり北海道小樽市石狩湾で行った。レーダー観測 は基本的には 3 時間毎に実施した。ドップラーレー ダーは図 1 の中心地点、小樽市石狩湾新港の小樽開 発建設部小樽港湾建設事務所の屋上に設置し、レー

* 正会員 神戸商船大学 （T658-0022 神戸市東灘区深江南町5-1-1）

** 非会員，第 4 管区海上保安本部 （干455-8528 名古屋市港区入船 2 丁目 3-12）

***非会員 北海道大学大学院理学研究科 （广060-0810 札幌市北区北10条西8丁目) 


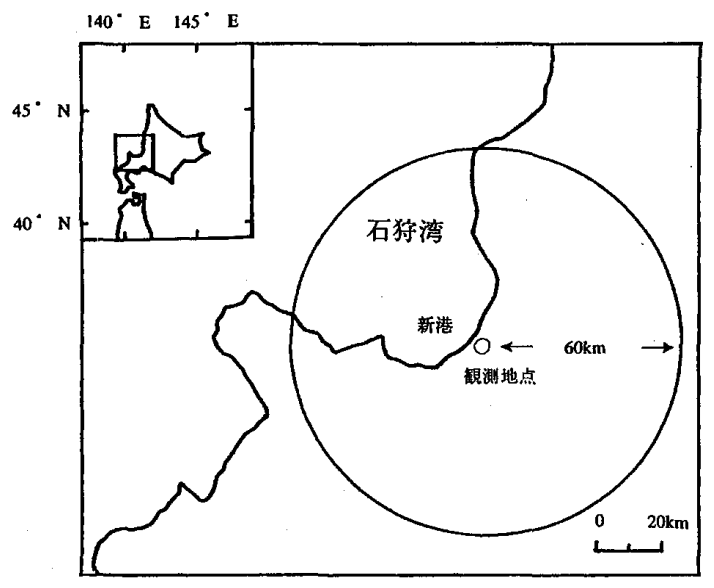

図 1 ドップラーレーダー観測地点

ダーアンテナ高度は海面上約 $28 \mathrm{~m}$ であった。レー ダー観測地点の沖合 $5 \mathrm{~km}$ 、水深 $25 \mathrm{~m}$ の所には超音 波式の流向流速計と波高波向計（圧力式と併用）が 設置されており、観測海域での海潮流の流向と流速、 波高と波向方位が 1 時間毎に観測された。

波高計は、超音波で海底から海面までの距離を計 測する超音波式波高計と、海面の上下動に伴う水位 変化を海底で水圧変化として計測する水圧式波高計 の、両方の波高計を備えた複合型波高計である。砕 波などの影響が大きくて超音波式波高計では波高計 測が不可能な場合には、水圧式波高計で計測される。 波向方位は流向流速計と波高計を用いて、波の水粒 子運動から波向方位を求方法を用いている。そ のため、波高が低い場合やうねりと風浪が混在して いる場合には、水粒子運動はそれらの影響を大きく 受けて複雑な運動となるため、正確な波向方位が得 られない(5),(6)。

\section{2 ドップラーレーダー}

表 1 に観測に用いたドップラーレーダーの仕様概
表 1 ドップラーレーダーの仕様概要

\begin{tabular}{ll}
\hline \multicolumn{1}{c}{ 項目 } & \multicolumn{1}{c}{ 仕様 } \\
\hline 観測モード & $(1) \quad(2)$ \\
周波数 & $9410 \mathrm{MHz}$ \\
出力 & $40 \mathrm{kw}$ \\
アンテナ直径 & $1.2 \mathrm{~m}$ \\
アンテナ回転数 & $1 \mathrm{rpm}$ \\
アンテナ高度 & $28 \mathrm{~m}$ (平均海面上) \\
ビーム幅 & $2 \mathrm{deg}$
\end{tabular}

パルス繰り返し周波数（1） $1500 \mathrm{pps}$ （2） $750 \mathrm{pps}$

$\begin{array}{lll}\text { パルス幅 } & \text { (1) } 0.4 \mu \mathrm{s} & \text { (2) } 0.8 \mu \mathrm{s}\end{array}$

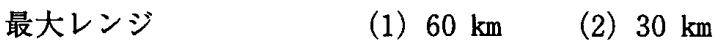

表中の (1)はドップラーモード、(2)は直交 2 偏波モード を示す。

要を示す。ドップラーレーダーは舶用レーダーに ドップラーシフトを得るための回路を付加して改良 した $3 \mathrm{~cm}$ 波レーダーで、観測モードとしてはドップ ラーモードと直交 2 偏波モードの 2 モードを持って いる。海面状況の観測にはこのドップラーモードを

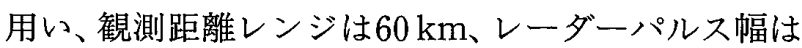
$0.4 \mu \mathrm{s}$ で観測を行った。レーダー反射波のドップ ラーシフトを得るため、回転数は通常の舶用レー ダーのもの (20〜30 rpm程度)よりかなり遅く $1 \mathrm{rpm}$ である。

ドップラーレーダーのシステム概要図を図 2 に示 す。レーダー電波はアンテナから発信されると共に コヒーレント回路に分配されて保存される。レー ダー反射波として受信される海面反射信号は、コ ヒーレント回路で保存されていた発信信号と位相検 波器で混合され、ドップラー信号の位相が得られる。 その位相はドップラー処理装置でパルスペアー方式 によって処理され、レーダービーム方向のドップ

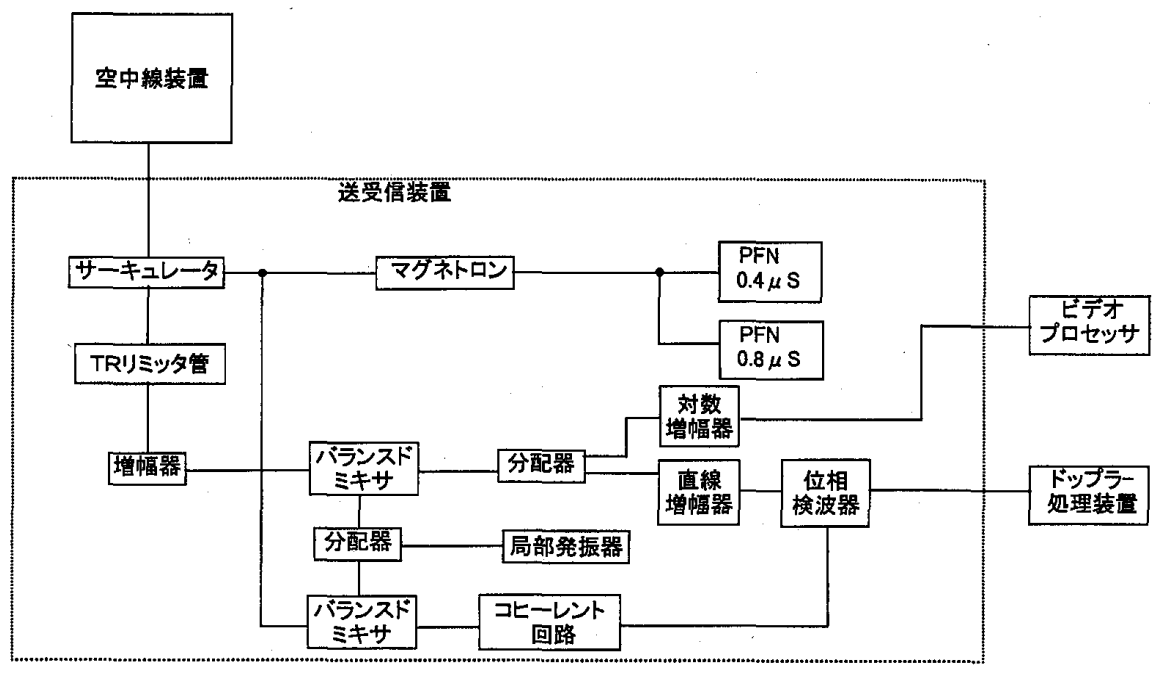

図 2 ドップラーレーダーのシステム概要 
ラー速度とその分散が得られて観測データとして記 録される。

ドップラーレーダーの観測データとしては観測方 位 1 度毎、距離 $250 \mathrm{~m}$ 毎の $62.5 \mathrm{~m}$ 区間のドップラー 速度の平均と分散が記録される。本解析では、ドッ プラーレーダーの海面反射信号強度が十分に強い観 測距離が $2 \mathrm{~km}$ から $10 \mathrm{~km}$ の区間の海面反射信号を 解析データとした。本観測で用いたドップラーレー ダー装置とドップラー信号処理の方法についての詳 細は、それぞれ上田 ${ }^{(7),(8)}$ と青柳(9)によって報告され ている。

\section{3. 解析結果}

\section{1 観測地点の観測データ}

先ず観測期間中の解析可能なケースを調べるた め、毎09時の観測地点の各種観測值 (以下、観測地 点風向・風速・波高・波向方位・波周期とする。）と 気象庁発行の沿岸波浪概況図(以下、波浪図とする。) から得た小樽湾での各種解析值 (以下、波浪図風向・ 風速・波高・波向方位・波周期とする。）との比較を 基に、観測地点での観測值の精度や有効性などを調 查した。

図 3 に観測地点風向と波浪図風向の関係を示す。 図からは両風向が 3 方位以上異なっている場合が多 く見受けられた。このような場合は風速が $5 \mathrm{~m} / \mathrm{s}$ 以 下と風が弱かった場合に多く見受けられた。このよ うに弱風時には観測地点風向は波浪図風向と大きな 差を生じる可能性があることに注意する必要があ る。

図 4 に観測地点風速と波浪図風速の関係を示す。 観測地点風速の方が波浪図風速よりも幾分高い傾向 を示した。両風速がかなり異なっていた場合は、風 向にもかなり差が生じていた。又、一部には風向は 一致していたが風速にかなりの差が見られた場合も あった。風の観測デー夕は観測日原簿に基づいたも のであり、観測日原簿には毎時間の観測記録が記載 されている。この観測日原簿によると、この場合は 風が 1 時間で大きく変化した時であった。

図 5 に観測地点波向方位と波浪図波向方位の関係 を示す。四から両波向方位が 3 方位以上異なった場 合がかなり見受けられ、その多くは観測地点波向方 位が北東方向で、波浪図波向方位が北－西～南方向 の場合であった。これらのように波向方位が大きく 異なった場合は、総じて波高が低かった場合に生じ ている。特に波高が低い時で波向方位とは異なった 方向から風が吹く場合には、観測地点波向方位の精 度や信頼性は低いと考えられる。

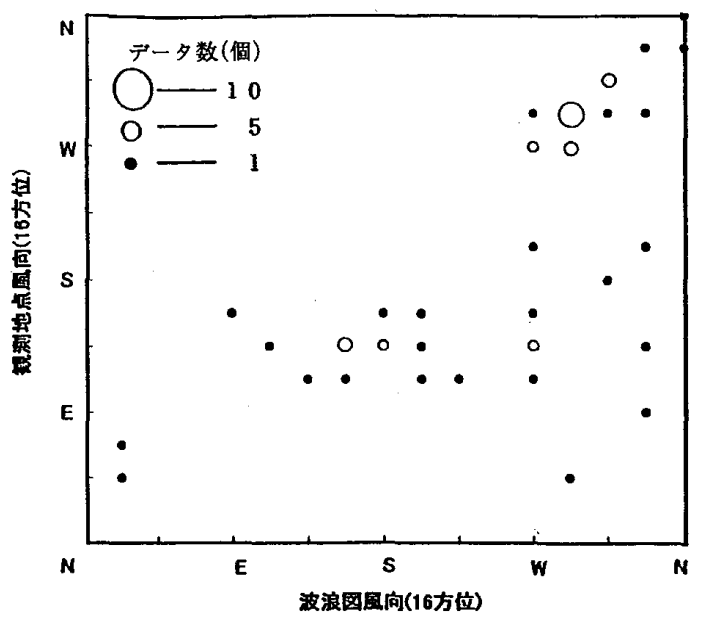

図 3 観測地点風向と波浪図風向

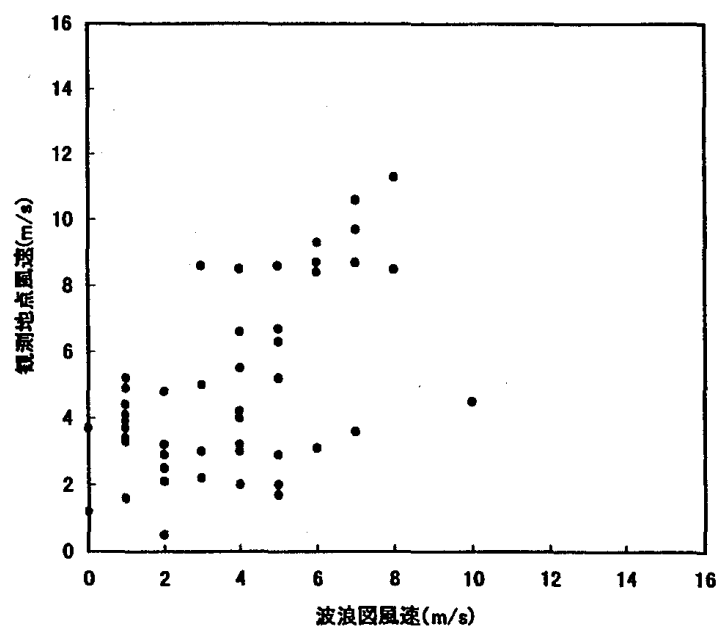

図 4 観測地点風速と波浪図風速

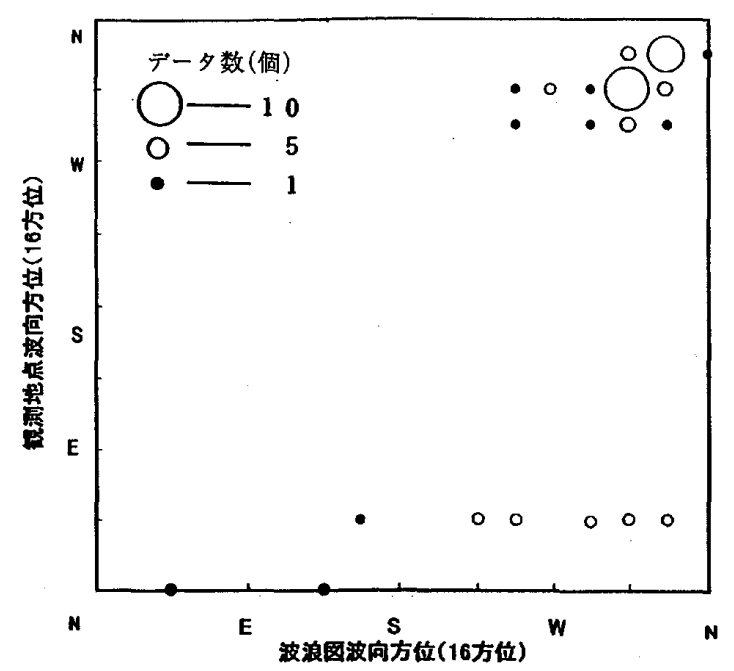

図 5 観測地点波向方位と波浪図波向方位

図 6 に観測地点波高と波浪図波高の関係を示す。 波浪図波高の方が観測地点波高より少し高い傾向を 示すが、 $1 \mathrm{~m}$ 以内で比較的よく一致する。波高に $1 \mathrm{~m}$ 以上の差が生じた場合は全て波浪図波高の方が観測 


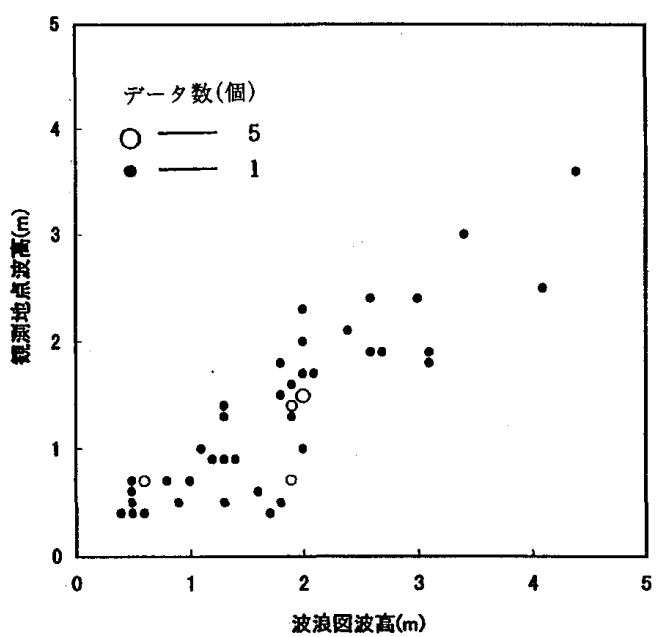

図 6 観測地点波高と波浪図波高

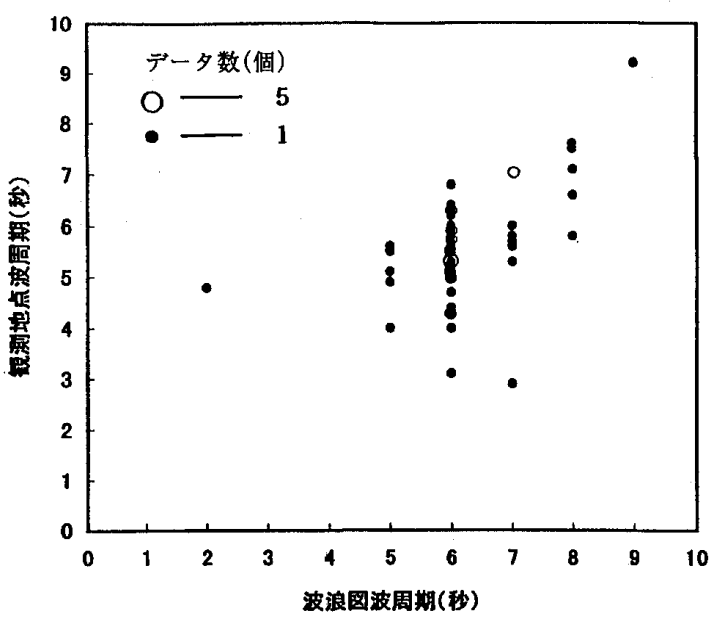

図 7 観測地点波周期と波浪図波周期

地点波高より高い值を示した。

図 7 に観測地点波周期と波浪困波周期の関係を示 す。波高と同様に、波浪図波周期は観測地点波周期 よりも少し長い傾向を示す。波周期に 2 秒以上の差 が生じたのは、1例を除いて波浪図波周期が観測地 点波周期より長い周期を示した。

以上のように波高が $1 \mathrm{~m}$ 以下で、特に波向方位と 風向が一致しない場合や風が急変していたような場 合、観測地点の観測波向方位の精度や信頼性は低い と考えられ、解析データとして用いるには疑問が残 る。従って、このような場合の観測デー夕は本解析 のデータベースからは除外した。又、波浪図波向方 位・波高・波周期は観測地点でのそれぞれの観測値 よりも幾分大きい值を示す傾向を持つことも判っ た。これらの観測結果の比較検討を基に、ドップラー レーダーの海面反射信号強度が十分強く、風も比較 的強くて (風速約 $5 \sim 11 \mathrm{~m} / \mathrm{s}$ ) 波も比較的高く（波高 約 $1 \sim 3.4 \mathrm{~m}$ )、そして風や波などが急変していない
ような観測状況を観測データの中から31ケースを選 出し、ここでの解析対象のデータベースとした。

\section{2 海面反射信号のドップラー特性}

ドップラーレーダーの観測データは方位 1 度毎、 距離 $250 \mathrm{~m}$ 毎の反射信号のドップラー速度である。 各観測方位のドップラー速度は、観測距離 $2 \mathrm{~km}$ か $10 \mathrm{~km}$ の区間で得られた $250 \mathrm{~m}$ 毎の32個のドップ ラ一速度の平均值とした。本解析では、各観測方位 のドップラー速度の内で、最大のドップラー速度を 得な観測方位を「ドップラー方位」と定義する。ドッ プラ一方位は 10 度単位で求めた。又、そのドップラー 方位のドップラー速度を単に「ドップラー速度」と 定義する。

レーダー海面反射信号のドップラーシフトは、海 面状況の種々の要因によって生じている。その物理 的要因として考えられるものとして、（1）波飛沫の 風による飛散、（2）海潮流、（3）波の伝搬などが挙 げられる。先ず波飛沫の影響について調查した。風 と波は相互に密接に関係し、風向と波が伝搬してく る方向（波向方位）とはかなり良く一致しているこ とが多い。そのため、解析データベースの中から風 向とドップラーレーダー観測によって求めたドップ ラー方位を比較したところ、再者が大きく異なる 2 ケースが見出された。

表 2 にその 2 ケース、1月20日と24日の風とドッ プラーレーダーの観測值を示す。20日は風は $2.9 \mathrm{~m} / \mathrm{s}$ と高くなく波飛沫はあまりなかったかもしれない が、24日は風速は $10 \mathrm{~m} / \mathrm{s}$ 高く多くの波飛沫が生じ ていたと考えられる。両日とも、ドップラー方位は ともに320度であったが、両日の風向はそれぞれSE (225度) とWSW (247.5度) でドップラー方位とは 約80～100度も大きく異なる。波飛沫は風によって風 下方向に飛散されるはずなので、ドップラ一方位と 同じような方位になるはずであるが大きく異なっい る。従って、レーダーの海面反射信号に波飛沫の飛 散が大きく影響し、その影響がドップラーシフトを 生じさせる主な要因になったとは考え難い。

表 2 観測地点風向・風速とドップラー方位・速度

\begin{tabular}{|c|c|c|c|c|}
\hline \multirow[b]{2}{*}{ 観測日時 } & \multicolumn{2}{|c|}{ 観測地点 } & \multicolumn{2}{|c|}{ ドップラーレーダー観測 } \\
\hline & 風向 & 風速 $(\mathrm{m} / \mathrm{s})$ & 方位（度） & 速度 $(\mathrm{m} / \mathrm{s})$ \\
\hline 1 月 20 日 09 時 & SE & 2.9 & 320 & 1.9 \\
\hline 1 月 24 日 03 時 & WSW & 10.0 & 320 & 3.0 \\
\hline
\end{tabular}

次に海潮流の影響について調査する。図 8 と 9 に 観測地点での海潮流の流向及び流速とドップラー方 位及び速度の関係を示す。この四の海潮流の流向は、 


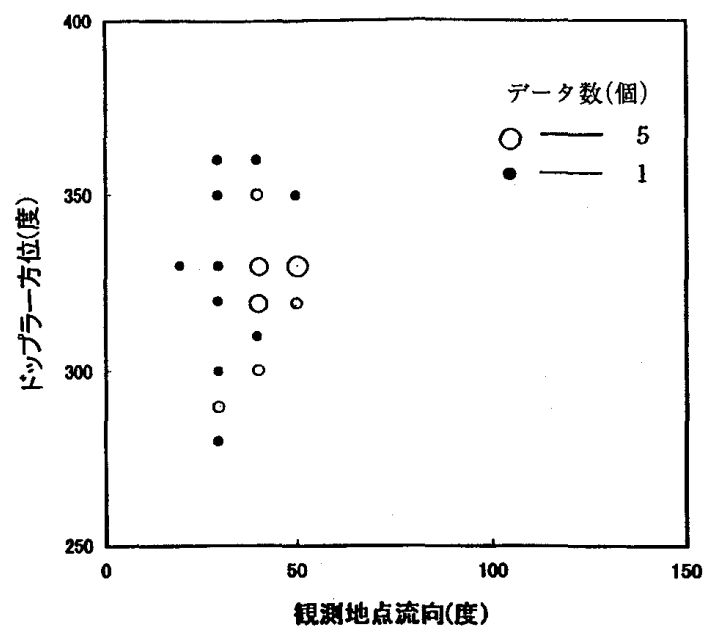

図 8 ドップラー万位と観測地点流向

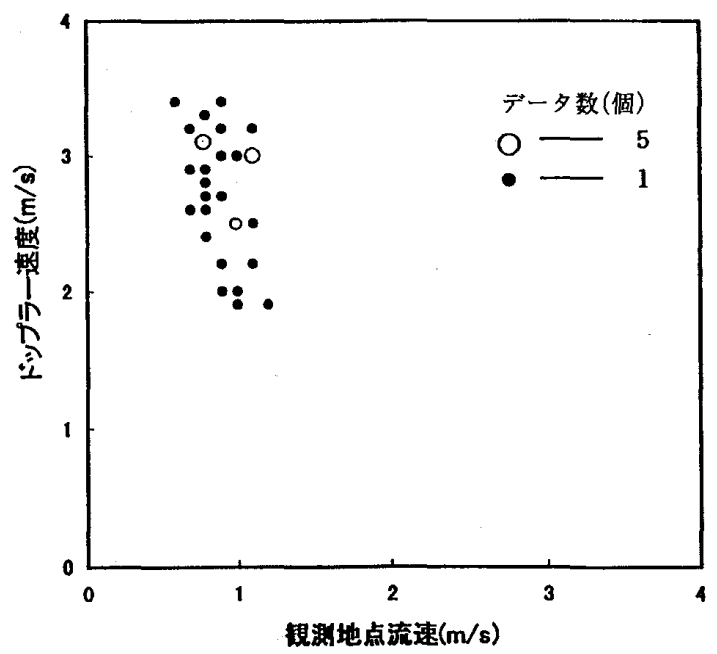

困 9 ドップラー速度と観測地点流速

ドップラー方位と比較するため、通常の流向の「流 れて行く方向」を示しているのではなく、「流れて来 る方向」を示している。ドップラー方位と速度はそ れぞれ280〜360度、1.9〜3.4 m/sの範囲の值を取っ

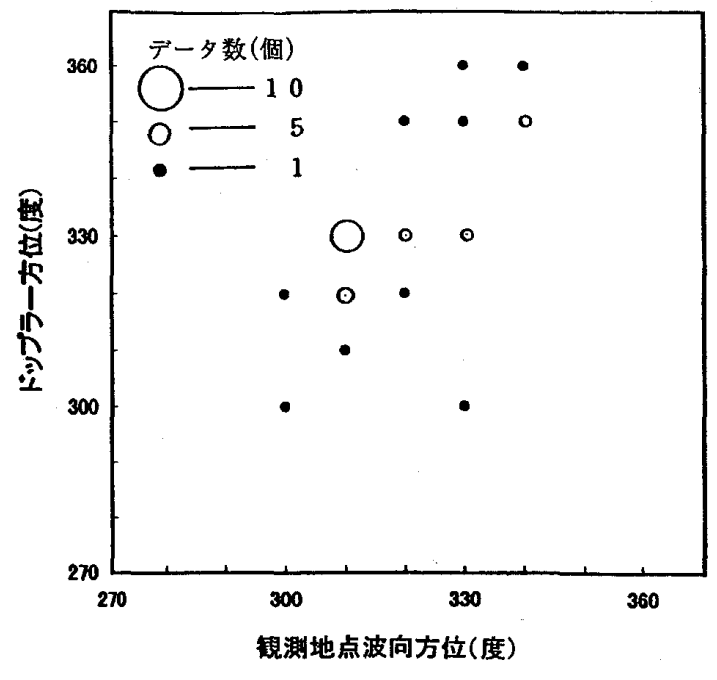

図10 ドップラー方位と観測地点波向方位

ているが、観測地点での海潮流の流向と流速はそれ

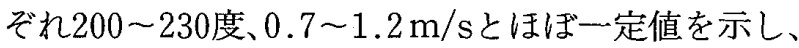
両者の間には強い相関は見受けられない。レーダー の海面反射信号には幾分かは海潮流の影響は含まれ ている可能性はあるが、レーダーの海面反射信号に 海潮流が大きく影響し、その影響がドップラーシフ 卜を生じさせる主な要因になったとは考え難い。

最後にレーダーの海面反射信号のドップラーシフ トと波との関係について調査した。観測地点波向方 位とドップラー方位の関係を図10に示す。ドップ ラー方位は観測地点波向方位と 30 度以内でよく一致 している。従って、ドップラー方位は観測地点波向 方位と強い相関を持ち、海面反射信号のドップラー シフトは波の伝搬方向が強く影響すると考えられ る。又、四11に観測地点波周期から推定した有義波 の位相速度とドップラー速度との関係を示す。両者 の間には相関係数が約 0.92 と高い相関が認められる

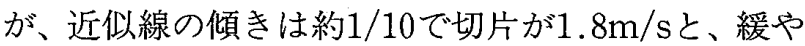

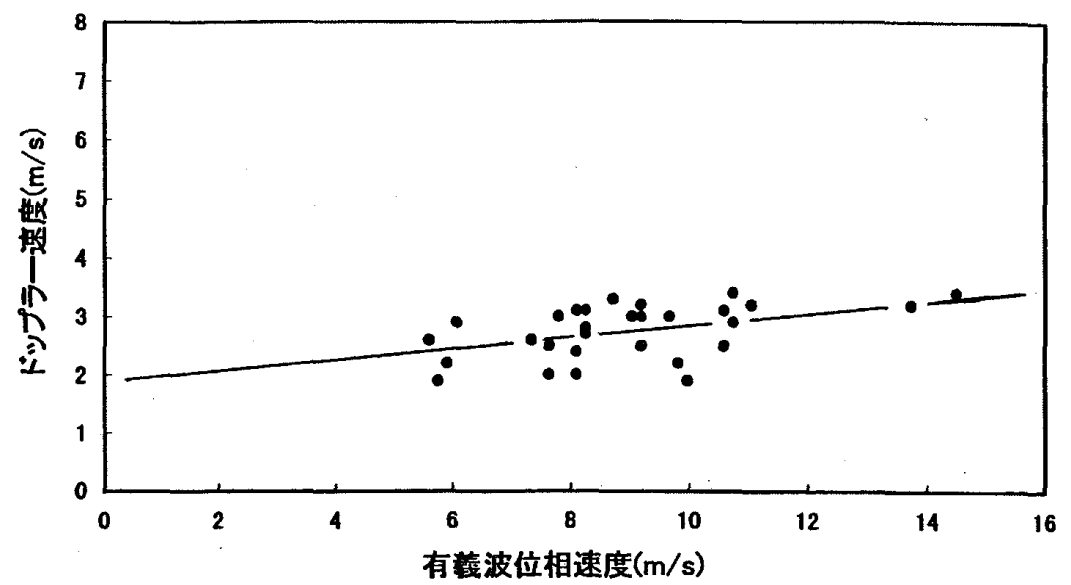

図11 ドップラー速度と観測地点に扮ける推定有義波位相速度 図中の直線は傾き 0.1 、切片 1.80 近似線。 
かな傾きを持った近似線となる。近似線がゼロ点を

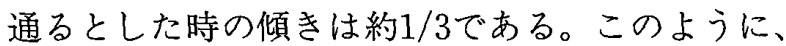
ドップラ一速度はドップラーシフトを生じさせる要 因の中では推定有義波の位相速度と良い比例関係を 示し、海面反射信号のドップラーシフトは波の伝搬 速度が大きく影響すると考えられる。

レーダー海面反射信号のドップラーシフトを生じ させる要因としては、波の伝搬と同様に波飛沫や海 潮流などの影響も考えられるが、以上の解析からは、 レーダー海面反射信号のドップラーシフトは、波飛 沫や海潮流の影響よりも波の伝搬の影響をより大き く受けると考えられる。ドップラ一速度と波の位相 速度との関係で両者の近似線の傾きがかなり緩やか なのは、解析デー夕数、風速や波浪の範囲が限られ ていることもあるが、波飛沫や海潮流などの影響が、 弱くではあるがある程度影響していることが一因で あるとも考えられる。しかし、これらの関係をより 明らかにするには、今後、より多くの観測データを 蓄積し、それらの解析を必要とする。

\section{4. 結 果}

波浪などの海面状況に関する情報は航海の安全や 運航効率の向上、そして防災などにとって必要不可 欠なものと考えられる。ここでは、1991年12月14日 から1992年 1 月31日の合計 49 日間、北海道小樽湾で 実施したドップラーレーダーによる海面状況の観測 デー夕を基に、海面状況が解析対象になりうる31 ケースを選出し、それらの観測データを基にレー ダーの海面反射信号と海面状況の相互関係や特性に ついて解析を行った。

ドップラーレーダー観測で得たドップラー方位や 速度は、ドップラーシフトを生じさせる可能性のあ る波飛沫や海潮流とは強い相関を示さなかった。一 方、ドップラー方位は波向方位と強い相関を示しほ ぼ一致した。又、ドップラー速度は観測周期から推 定した有義波の位相速度と強い相関を示し、1/10〜 $1 / 3$ 程度の比例係数で比例した。このように、波飛沫 や海潮流はレーダーの海面反射信号のドップラーシ フトに弱くではあるが影響するであろうが、波の伝 搬がレーダーの海面反射信号のドップラーシフトを 生じさせるのに強く影響していることが判った。

\section{参 考 文 献}

（1）石田廣史 - 井上篤次郎 - 林 美鶴 - 細田龍介： 舶用レーダーによる波浪観測と解析一 I，一陸
上観測点における実験一, 日本航海学会論文集, 第90号，23-31，1994.

(2) Ishida, H., T. Inoue, M. Hayashi, S. Shiotani, R. Hosoda and Y. Kunitake : Wave Observation Aparatus by Marine Radar and Evaluation of its Analytical Results, TECHNO -OCEAN '94 Internatl. Symp., Proc. vol.1, 469-474, 1944.

（3）石田廣史・井上篤次郎・塩谷茂明・市川義文・ 細田龍介：舶用レーダーによる波浪観測一 II, 一実船観測一, 日本航海学会論文集, 第 96 号, 47-52, 1997.

(4) Ishida, H., T. Inoue, S. Shiotani, Y. Ichikawa and R. Hosoda : Marine Radar Wave Observation System, J. of Japan Institute of Navigation, Commemorative Issue of 50th Anniversary, 31-39, 1998.

（5）株式会社カイジョー：複合型超音波式波高計 USW-150カタログ.

（6）株式会社カイジョー：超音波流速計RC-500力 タログ.

（7）上田 博 - 竹本明生 - 菊地勝弘 - 尾崎尚則：都 市の豪雪災害の予測と軽減·防除に関する研究, 文部省科学研究費重点領域研究「自然災害の予 知と防災力」研究成果, pp609，1994.

（8）上田 博：風を見る，電子通信学会誌，vol.69, 907-911， 1986.

（9）青柳二郎：ドップラー信号処理とレーダー装 置，気象研究所技術報告，第19号，7-23，1986.

\section{質 疑 応 答}

河合雅司(富山商船高等専門学校)：図 2 において有 義波位相速度が $0 \mathrm{~m} / \mathrm{s}$ の時でもドップラー速度約 $1.8 \mathrm{~m} / \mathrm{s}$ 名存しており、この速度は波飛沫や海潮 流等の影響とのことですが、この速度は波飛沫や 海潮流の変化により、影響を受けるのでしょうか。

石田廣史：レーダー海面反射信号のドップラーシフ トの主な原因は波浪の伝搬によると考えられます が、同時に波飛沫や海潮流の影響も少しは含まれ ていると考えられます。しかし、それらの影響は 小さいと考えます。また、解析に用いました気象 状況の範囲が限られていたため、近似線の切片が $1.8 \mathrm{~m} / \mathrm{s}$ になったとも考之ます。観測時の気象状況 の範囲が広がって解析デー夕数が増えると、この 切片も当然変化すると考之ます。 